\title{
Growth and form responses to pre-commercial thinning regimes in aerially seeded jack pine stands: 5 th year results
}

\author{
by D.M. Morris ${ }^{1}$, C. Bowling ${ }^{2}$ and S.C. Hills ${ }^{1}$
}

In 1986, a thinning trial was established in a 9-year-old jack pine stand near Dryden, Ontario. Four blocks consisting of five thinning regimes $(1 \mathrm{~m} \times 1 \mathrm{~m}, 1.5 \mathrm{~m} \times 1.5 \mathrm{~m}, 2 \mathrm{~m} \times 2 \mathrm{~m}, 2.5 \mathrm{~m}$ $\times 2.5 \mathrm{~m}, 3 \mathrm{~m} \times 3 \mathrm{~m}$ ) and a control plot were established using a randomized complete block design. Once thinned, a series of measurements were taken in 1986 and repeated in 1991 to determine growth and form responses. Results identified highly significant responses for $\mathrm{DBH}$ growth and individual stem volume growth. Height response did not vary among the spacing levels. Changes in crown dimensions and stem taper were used to evaluate form responses to thinning. A highly significant decline in all form variables was found in response to increased spacing. Although the increased growth in individual trees provides an opportunity to produce a wider array of products, it appears to be at a cost of reduced form characteristics. Specific management implications for the Dryden Crown Forest are discussed.

Key words: jack pine, pre-commercial thinning, growth and form responses
Un essai d'éclaircie a été effectué en 1986 dans un peuplement de pin gris âgé de 9 ans situé près de Dryden en Ontario. Quartre blocs représentant cinq niveaux d'éclaircie $(1 \mathrm{~m} \times 1 \mathrm{~m}, 1.5 \mathrm{~m} \times$ $1.5 \mathrm{~m}, 2 \mathrm{~m} \times 2 \mathrm{~m}, 2.5 \mathrm{~m} \times 2.5 \mathrm{~m}, 3 \mathrm{~m} \times 3 \mathrm{~m}$ ) ainsi qu'une parcelle témoin ont été établis selon une distribution complètement aléatoire. Suite à l'éclaircie, un série de mesure a été effectuée en 1986 et répétée en 1991 afin de déterminer la croissance et les modifications de la forme des arbres. Les résultats ont indiqué des réponses très significatives au niveau de la croissance en diamètre et en volume pour chacune des tiges. La croissance en hauteur n'a pas beaucoup varié en fonction des niveaux d'éclaircie. Les changements dans les dimensions de la cime et le défilement de la tige ont été utilisés pour évaluer les modifications des formes suite à l'éclaircie. Une diminution très significative de toutes les variables associées à la forme a été identifiée en réponse à l'augmentation de la distance entre les tiges. Même si la croissance accrue de chaque arbre constitue une possibilité de produire un plus grand éventail de produits, il semble que cela s'effectue au détriment des caractéristiques de la forme. Les implications spécifiques au niveau de l'aménagement des forêts publique de la région de Dryden sont abordées.

Mots clés: pin gris, éclaircie précommerciale, réponses au niveau de la croissance et de la forme.

\section{Introduction}

Although jack pine (Pinus banksiana Lamb.) comprises approximately $15 \%$ of the total volume of growing stock within the boreal forest region of Ontario (Howse 1984), it is second only to black spruce (Picea mariana (Mill.) B.S.P.) as the most important commercial species harvested in Ontario. Jack pine contributes approximately $34 \%$, by volume, of the total conifer cut annually in Ontario (OMNR 1990). Of this harvest, $30 \%$ is used for sawlogs and the remaining 70\% for pulpwood (Davison 1984). Much of the natural jack pine forest of Ontario is fire-origin, with common associates of black spruce and trembling aspen (Populus tremuloides L.) (Sims et al. 1989). Jack pine is widely distributed throughout northern Ontario and is found most commonly on sandy and coarse loamy soils of the Podzolic and Brunisolic soil orders (USDA 1975). It can occur on fine, loamy soils of variable petrology and depth, on thin soils over the granites, and on metamorphosed rocks of the Canadian Shield (Schoenike 1976).

Jack pine is noted for its production of predominately serotinous cones, thereby accumulating seeds in the canopy seed bank with estimates as high as 4 million seeds ha ${ }^{-1}$ in well stocked stands (Rudolf 1965). Although the contribution to overall stand density from this natural source after harvest is difficult to pre-

\footnotetext{
${ }^{1}$ Ontario Ministry of Natural Resources, Ontario Forest Research Institute, Centre for Northern Forest Ecosystem Research, c/o Lakehead University, 955 Oliver Road, Thunder Bay, Ontario, Canada P7B 5E1.

${ }^{2}$ Ontario Ministry of Natural Resources, Northwest Region Science and Technology Section, 25th Side Road, R.R. \#1, Thunder Bay, Ontario, Canada P7C 4T9.
}

dict and tends to be patchy, their contribution combined with artificial regeneration efforts tend to leave stands overstocked (Van Damme and McKee 1990). It has been recommended that overstocked jack pine seedling and sapling stands with 5,000 or more trees ha- ${ }^{-1}$ should be thinned to improve growth and development. Otherwise, such stands may stagnate because natural thinning in jack pine stands is slow except on the best sites (Benzie 1977). It is known, in general terms, that overdense stands result in spindly trees and early mortality from competition, and that understocking can result in heavy branching and poor form (Rudolf 1951).

Thinning, as an intensive silvicultural tool, represents one of the principal means to increase tree productivity beyond that which might be achieved under purely natural conditions (Smith 1984). However, Vassov and Baker (1988) noted that there is little information about the responses in growth and form of jack pine to pre-commercial thinning. Therefore, the purpose of this study was to address this shortcoming.

\section{Materials and Methods Plot Establishment}

An area in northwestern Ontario approximately $30 \mathrm{~km}$ from Dryden, Ontario was selected for the thinning trial (Fig. 1). The site represents a FEC soil Type S2 (Sims et al. 1989) consisting of a deep, medium-textured sand. This area had been harvested using a tree-length cut and skid operation in 1975, site prepared in 1976 using barrels and chains, and aerially seeded in the winter of 1977 . The current stand, therefore, was 9 years of age when the thinning treatments were conducted.

In October, 1986, 24 plots $(24 \mathrm{~m} \times 24 \mathrm{~m})$ were established 

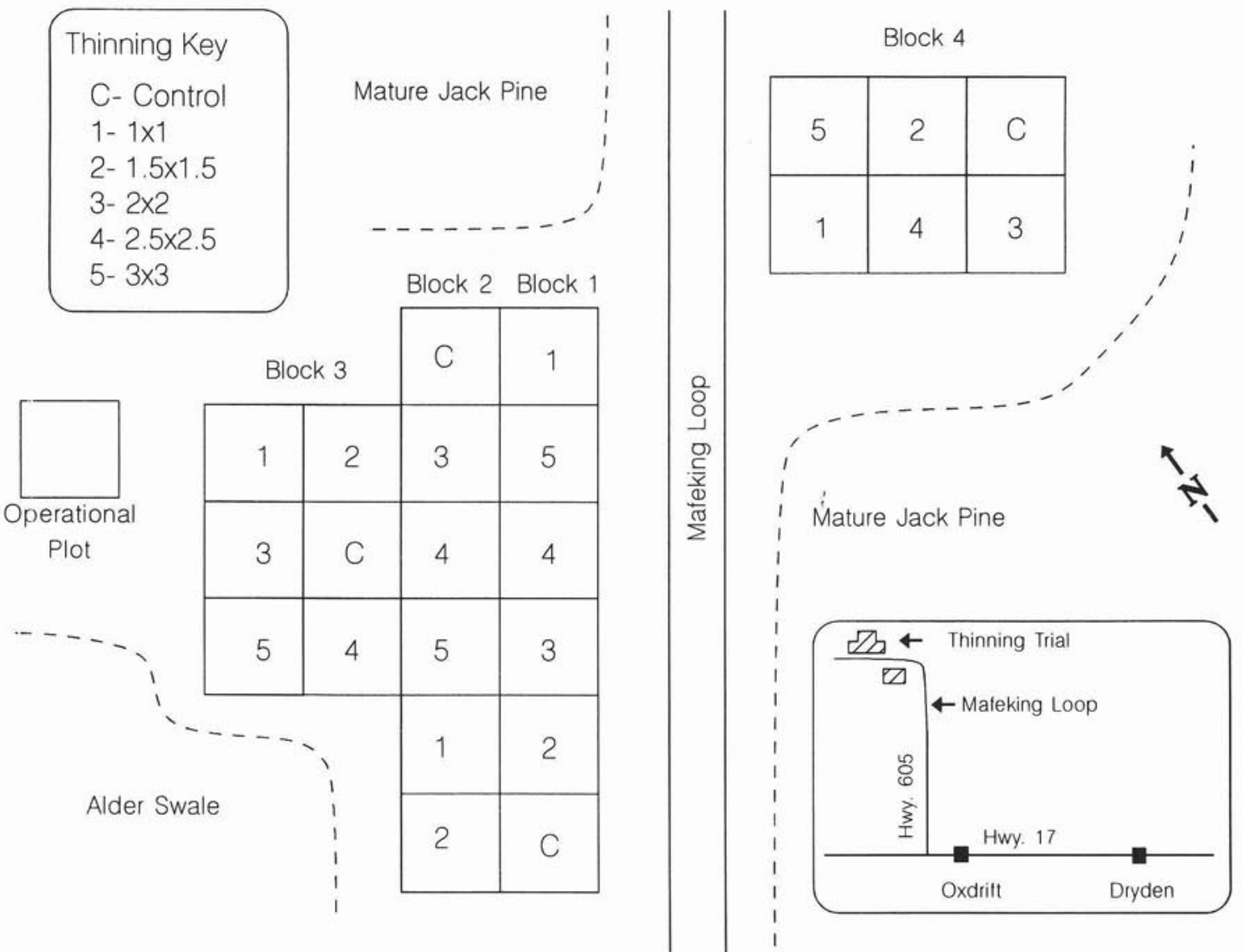

Figure 1. Sketch map detailing the experimental layout of thinning trial.

using a randomized complete block design. Within each of four blocks, five thinning regimes $(1 \mathrm{~m} \times 1 \mathrm{~m}, 1.5 \mathrm{~m} \times 1.5 \mathrm{~m}, 2 \mathrm{~m}$ $\times 2 \mathrm{~m}, 2.5 \mathrm{~m} \times 2.5 \mathrm{~m}$, and $3 \mathrm{~m} \times 3 \mathrm{~m})$ and a control were randomly assigned to the plots (Fig. 1). Temporary grid lines, at the corresponding spacing, were placed on the ground within each plot. These lines were then walked and the appropriate trees selected and marked (closest to the assigned coordinate) for retention. Spacing took precedence over other considerations (e.g., insect damage) when selecting trees, but if more than one tree was near the grid point then the best individual, in terms of growth and form, was selected. All unmarked trees were removed using brush saws. The remainder of the stand was operationally thinned later in the fall of 1986 . One plot was established in this area (Fig. 1) and was used as a comparison to experimental thinnings (Table 1).

Once the prescribed thinning was completed, 36 trees plot $^{-1}$ were randomly selected as sample trees and permanently tagged for remeasurement in subsequent years. Trees within the outer three metres of each plot were considered as buffers and, therefore, were not eligible for selection as sample trees. In 1991, the plots were re-established and as many trees as possible were relocated (e.g., numbered tag still identifiable).

\section{Data Collection and Analysis}

In 1986 and 1991, total height, DBH, and diameter at 0.3 of the total height were measured. Other measurements taken in
1991 included: live crown height, average crown width, crown class (dominant, codominant, intermediate, and suppressed), and distances to the five nearest neighbours. Using total height and diameter at 0.3 of the total height, individual stem volumes were calculated using equation (7) described by Forslund (1991), as follows:

$$
V=3 / 7(1-Y)^{(-4 / 3)} \frac{\pi D^{2} H}{4}
$$

where $V=$ stem volume, $Y=h / H, h$ is the height to the measurement position from the base of the stem and $H$ is the total stem height, $D=$ diameter at the measurement position. Stem taper was calculated using equation (15) presented by Forslund (1991), as follows:

$$
T=\frac{1.40 H}{D_{0.3}}
$$

where $T=$ stem taper, $H=$ total stem height, $D_{0.3}=$ diameter at 0.3 of total stem height. Using the average intertree distances for each sample tree, estimates of stems $\mathrm{ha}^{-1}$ were generated and used to calculate mean stem volumes $\mathrm{ha}^{-1}$. The data from 1986 and 1991 were summarized by spacing level (Table 1).

Analysis of variance performed on the 1986 data (prethinning condition) indicated significant difference among 


\begin{tabular}{|c|c|c|c|c|c|c|c|c|c|}
\hline \multirow[b]{2}{*}{$\begin{array}{l}\text { Thinning } \\
\text { level }\end{array}$} & \multirow[b]{2}{*}{$n$} & \multirow[b]{2}{*}{$\begin{array}{c}\text { Height } \\
(\mathrm{cm})\end{array}$} & \multirow[b]{2}{*}{$\begin{array}{l}\text { DBH } \\
(\mathbf{c m})\end{array}$} & \multirow[b]{2}{*}{$\begin{array}{c}\text { Stems }^{1} \\
\text { ha }^{-1}\end{array}$} & \multicolumn{2}{|c|}{ Stem volume ${ }^{2}$} & \multirow{2}{*}{$\begin{array}{c}\text { Crown } \\
\text { width } \\
(\mathrm{cm})\end{array}$} & \multirow{2}{*}{$\begin{array}{c}\text { Crown } \\
\text { length } \\
(\mathrm{cm})\end{array}$} & \multirow[b]{2}{*}{ Taper $^{3}$} \\
\hline & & & & & $\begin{array}{l}\operatorname{tree}^{-1} \\
\left(\mathbf{d m}^{3}\right)\end{array}$ & $\begin{array}{l}\mathbf{h a}^{-1} \\
\left(\mathrm{~m}^{3}\right)\end{array}$ & & & \\
\hline \multicolumn{10}{|c|}{1986 Data (immediately after thinning) } \\
\hline Control & 131 & $\begin{array}{c}307 \\
(76.2)^{4}\end{array}$ & $\begin{array}{c}3.2 \\
(1.4)\end{array}$ & & $\begin{array}{c}2.7 \\
(2.4)\end{array}$ & & & & $\begin{array}{c}128 \\
(28.5)\end{array}$ \\
\hline $1 \times 1$ & 130 & $\begin{array}{c}283 \\
(58.5)\end{array}$ & $\begin{array}{c}2.6 \\
(1.0)\end{array}$ & & $\begin{array}{c}1.7 \\
(1.2)\end{array}$ & & & & $\begin{array}{c}134 \\
(29.4)\end{array}$ \\
\hline $1.5 \times 1.5$ & 108 & $\begin{array}{c}275 \\
(71.0)\end{array}$ & $\begin{array}{c}2.7 \\
(1.1)\end{array}$ & & $\begin{array}{c}1.9 \\
(1.9)\end{array}$ & & & & $\begin{array}{c}128 \\
(24.4)\end{array}$ \\
\hline $2 \times 2$ & 110 & $\begin{array}{c}261 \\
(73.8)\end{array}$ & $\begin{array}{c}2.5 \\
(1.4)\end{array}$ & & $\begin{array}{l}1.9 \\
(2.7)\end{array}$ & & & & $\begin{array}{c}128 \\
(26.5)\end{array}$ \\
\hline $2.5 \times 2.5$ & 128 & $\begin{array}{c}267 \\
(58.1)\end{array}$ & $\begin{array}{c}2.6 \\
(1.1)\end{array}$ & & $\begin{array}{c}1.8 \\
(1.7)\end{array}$ & & & & $\begin{array}{c}125 \\
(23.7)\end{array}$ \\
\hline $3 \times 3$ & 112 & $\begin{array}{c}259 \\
(62.3)\end{array}$ & $\begin{array}{c}2.5 \\
(1.1)\end{array}$ & & $\begin{array}{c}1.6 \\
(1.2)\end{array}$ & & & & $\begin{array}{c}122 \\
(22.8)\end{array}$ \\
\hline Operational & 36 & $\begin{array}{c}310 \\
(67.9)\end{array}$ & $\begin{array}{c}3.0 \\
(1.2)\end{array}$ & & $\begin{array}{c}2.3 \\
(1.6)\end{array}$ & & & & \\
\hline \multicolumn{10}{|c|}{1991 Data (5 years after thinning) } \\
\hline Control & 131 & $\begin{array}{c}507 \\
(109.3)\end{array}$ & $\begin{array}{c}5.2 \\
(2.2)\end{array}$ & $\begin{array}{c}20630 \\
(18859)\end{array}$ & $\begin{array}{c}8.8 \\
(7.6)\end{array}$ & $\begin{array}{c}126 \\
(135.5)\end{array}$ & $\begin{array}{c}62 \\
(28.9)\end{array}$ & $\begin{array}{c}354 \\
(111.6)\end{array}$ & $\begin{array}{c}155 \\
(42.9)\end{array}$ \\
\hline $1 \times 1$ & 130 & $\begin{array}{c}465 \\
(90.1)\end{array}$ & $\begin{array}{c}4.7 \\
(1.7)\end{array}$ & $\begin{array}{c}7588 \\
(2513)\end{array}$ & $\begin{array}{c}6.6 \\
(4.7)\end{array}$ & $\begin{array}{c}45 \\
(31.1)\end{array}$ & $\begin{array}{c}58 \\
(19.2)\end{array}$ & $\begin{array}{c}337 \\
(81.0)\end{array}$ & $\begin{array}{c}148 \\
(29.6)\end{array}$ \\
\hline $1.5 \times 1.5$ & 108 & $\begin{array}{l}473 \\
(98.6)\end{array}$ & $\begin{array}{c}5.3 \\
(1.9)\end{array}$ & $\begin{array}{l}3519 \\
(968)\end{array}$ & $\begin{array}{c}8.3 \\
(7.3)\end{array}$ & $\begin{array}{c}28 \\
(23.5)\end{array}$ & $\begin{array}{c}67 \\
(23.2)\end{array}$ & $\begin{array}{l}358 \\
(87.6)\end{array}$ & $\begin{array}{c}135 \\
(25.7)\end{array}$ \\
\hline $2 \times 2$ & 110 & $\begin{array}{c}430 \\
(103.8)\end{array}$ & $\begin{array}{c}5.2 \\
(2.0)\end{array}$ & $\begin{array}{l}2112 \\
(504)\end{array}$ & $\begin{array}{c}8.3 \\
(8.8)\end{array}$ & $\begin{array}{c}17 \\
(19.9)\end{array}$ & $\begin{array}{c}71 \\
(24.0)\end{array}$ & $\begin{array}{l}343 \\
(88.3)\end{array}$ & $\begin{array}{c}119 \\
(19.6)\end{array}$ \\
\hline $2.5 \times 2.5$ & 128 & $\begin{array}{l}437 \\
(84.6)\end{array}$ & $\begin{array}{c}5.7 \\
(1.7)\end{array}$ & $\begin{array}{l}1292 \\
(331)\end{array}$ & $\begin{array}{c}8.8 \\
(5.9)\end{array}$ & $\begin{array}{l}11 \\
(7.8)\end{array}$ & $\begin{array}{c}82 \\
(24.0)\end{array}$ & $\begin{array}{l}366 \\
(90.5)\end{array}$ & $\begin{array}{c}112 \\
(23.3)\end{array}$ \\
\hline $3 \times 3$ & 112 & $\begin{array}{l}437 \\
(78.3)\end{array}$ & $\begin{array}{c}5.9 \\
(1.6)\end{array}$ & $\begin{array}{l}1004 \\
(266)\end{array}$ & $\begin{array}{c}9.2 \\
(5.1)\end{array}$ & $\begin{array}{c}9 \\
(5.6)\end{array}$ & $\begin{array}{c}85 \\
(20.9)\end{array}$ & $\begin{array}{l}377 \\
(76.1)\end{array}$ & $\begin{array}{c}106 \\
(14.3)\end{array}$ \\
\hline Operational & 31 & $\begin{array}{c}512 \\
(100.5)\end{array}$ & $\begin{array}{c}6.0 \\
(2.2)\end{array}$ & $\begin{array}{l}2929 \\
(451)\end{array}$ & $\begin{array}{l}10.8 \\
(7.7)\end{array}$ & $\begin{array}{c}30 \\
(19.7)\end{array}$ & $\begin{array}{c}73 \\
(22.0)\end{array}$ & $\begin{array}{l}147 \\
(36.2)\end{array}$ & \\
\hline \multicolumn{10}{|c|}{ Relative growth rate } \\
\hline Control & & $\begin{array}{c}0.14 \\
(0.08)\end{array}$ & $\begin{array}{l}0.14 \\
(0.07\end{array}$ & & $\begin{array}{c}0.46 \\
(0.21)\end{array}$ & & & & \\
\hline $1 \times 1$ & & $\begin{array}{c}0.13 \\
(0.05)\end{array}$ & $\begin{array}{c}0.19 \\
(0.10)\end{array}$ & & $\begin{array}{c}0.59 \\
(0.26)\end{array}$ & & & & \\
\hline $1.5 \times 1.5$ & & $\begin{array}{c}0.15 \\
(0.06)\end{array}$ & $\begin{array}{c}0.24 \\
(0.12)\end{array}$ & & $\begin{array}{c}0.80 \\
(0.31)\end{array}$ & & & & \\
\hline $2 \times 2$ & & $\begin{array}{c}0.13 \\
(0.05)\end{array}$ & $\begin{array}{c}0.27 \\
(0.12)\end{array}$ & & $\begin{array}{c}0.90 \\
(0.42)\end{array}$ & & & & \\
\hline $2.5 \times 2.5$ & & $\begin{array}{c}0.13 \\
(0.05)\end{array}$ & $\begin{array}{c}0.28 \\
(0.12)\end{array}$ & & $\begin{array}{c}0.98 \\
(0.51)\end{array}$ & & & & \\
\hline $3 \times 3$ & & $\begin{array}{c}0.15 \\
(0.06)\end{array}$ & $\begin{array}{c}0.36 \\
(1.27)\end{array}$ & & $\begin{array}{c}1.27 \\
(0.69)\end{array}$ & & & & \\
\hline Operational & & $\begin{array}{c}0.13 \\
(0.05)\end{array}$ & $\begin{array}{c}0.20 \\
(0.05)\end{array}$ & & $\begin{array}{c}1.20 \\
(0.55)\end{array}$ & & & & \\
\hline
\end{tabular}

${ }^{1}$ Calculated using average intertree distances obtained in 1991.

${ }^{2} \mathrm{~A}$ stem volume ha ${ }^{-1}$ was generated for each sample tree based on individual stem volume $X$ an estimate of stems ha ${ }^{-1}$ (based on average intertree distances).

These values were summed and divided by the number of sample trees to determine a mean stem volume ha ${ }^{-1}$ for each thinning treatment.

${ }^{3}$ Taper is defined as the horizontal change in stem radius along the bole length. As a result, smaller numbers represent a greater degree of taper.

${ }^{4}$ Values in parentheses represent standard deviations.

treatment plots. In addition, significant correlations between the 1986 data and 1991 data were detected (Table 2) regardless of thinning level. In general, small trees remained small or large trees remained large even after being subjected to different thinning regimes. To test growth and form differences caused as a result of the thinning treatments independent of pretreatment size or form, a series of Analysis of Covariances were performed on the 1991 data using the corresponding 1986 data as a covariate. In the case of crown length and width, data for these variables were not collected in 1986 . Therefore, based on the reasonable relationship between $1986 \mathrm{DBH}$ and 1991 crown variables (Table 2: $r=0.74$ for crown width, $r=0.67$ for crown length), the $1986 \mathrm{DBH}$ was used as the best alter- native covariate. Since this experiment was designed to examine a single factor with quantitative treatments, the relationship between the main effect (thinning) and all the growth and form variables measured was examined by developing regression models, as described by Mize and Schultz (1985).

\section{Results and Discussion \\ Growth Responses}

Thinning theory is based on the generalization that the total production of cubic volume by a stand of given age and composition on a given site is constant and optimum for a wide range of densities (Smith 1962). Therefore, the objective of precommercial thinning is to regulate the amount and distribution 
Table 2. Pearson correlation matrix for 1986 and 1991 growth and form variables $(n=719)$

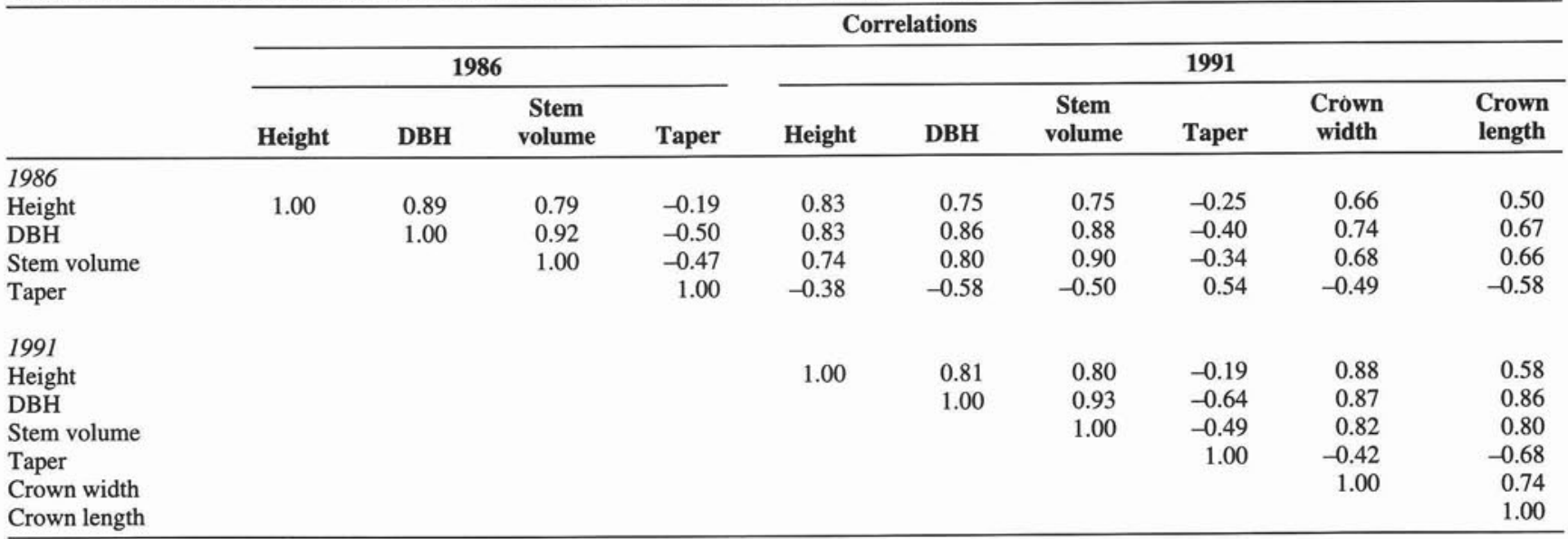

of growing space, thereby redistributing the growth potential of the remaining stand to fewer individuals. This concept, however, does assume that these remaining stems are capable of enhanced growth. The ability to respond to thinning is related to such variables as species, age, degree of suppression (intensity and length of time), and site.

The means for the growth variables (height, DBH, stem volume) were summarized (Table 1). However, correlation coefficients between 1986 and 1991 data collected for the same variable were positive and greater than 0.83 irrespective of thinning level (Table 2). This relationship suggests that the larger trees, prior to thinning, still remain as the larger trees five years after thinning. As a result of the relationship, it is more appropriate to concentrate on relative growth rate when comparing responses to the thinnings. Relative growth rates were calculated using the formula adopted from Ledig (1974), as follows:

$$
R G R=\left[\left(\operatorname{Var}_{2}-\operatorname{Var}_{1}\right) /\left(t_{2}-t_{1}\right)\right] / \operatorname{Var}_{1}
$$

where: $R G R$ is the relative growth rate for the variable being measured; Var $_{1}$ is the initial measurement of the given variable; $\mathrm{Var}_{2}$ is the final measurement; and $t_{1}$ and $t_{2}$ are the times when the measurements were taken. The results (Table 1) demonstrate a strong response to thinning in diameter (from $0.14 \mathrm{~cm}$ $\mathrm{cm}^{-1}$ year- $^{-1}$ for controls to $0.36 \mathrm{~cm} \mathrm{~cm}^{-1}$ year-1 $^{-1}$ for the widest thinning) and in individual stem volume (from $0.63 \mathrm{dm}^{3}$ $\mathrm{dm}^{3-1}$ year-1 for controls to $1.27 \mathrm{dm}^{3} \mathrm{dm}^{3-1}$ year-1 for the widest spacing). Height response varied only slightly from $0.13 \mathrm{~cm}$ $\mathrm{cm}^{-1}$ year-1 to $0.15 \mathrm{~cm} \mathrm{~cm}^{-1}$ year-1 with no clear relationship to thinning intensity. This lack of response has been documented by others for jack pine (Buckman 1964, Bella and DeFranceschi 1980 , Smith 1984) and is probably due to the relative weakness of the apical meristem as a photosynthate sink (Lanner 1985). Results from the analysis of covariance (Table 3 ), used to adjust for variations in pre-thinning size, confirmed that the thinning had a highly significant impact on DBH $(F$-ratio $=73.3)$ and individual stem volume $(F$-ratio $=32.7)$. The response models developed identified a significant linear trend (DBH: $p=0.000$; stem volume: $p=0.000$ ) from the controls to the widest thinning (Table 3; Fig. 2). Based on the linear nature of the curve, the maximum growth response for either $\mathrm{DBH}$ or stem volume has not been reached and a thinning greater than
$3.0 \mathrm{~m}$ might produce a greater growth response. Unpublished results from another thinning trial in the region agree with these results. In this case, a 15-year-old stand near Atikokan, Ontario (Durie Lake Trial) was thinned to $2 \mathrm{~m} \times 2 \mathrm{~m}$ spacing in 1986. As in this study (Table $1: 2 \mathrm{~m} \times 2 \mathrm{~m}$ spacing, for comparison), data collected in 1986 and 1991 were used to compute relative growth rates which, in turn, were used to compare the controls to the treated plots. In the Durie Lake trial, relative growth rates for height were $0.15 \mathrm{~cm} \mathrm{~cm}^{-1}$ year $^{-1}$ for both the control and treated plots, whereas both DBH $\left(0.11 \mathrm{~cm} \mathrm{~cm}^{-1}\right.$ year ${ }^{-1}$ - control, $0.19 \mathrm{~cm} \mathrm{~cm}^{-1}$ year-1 $^{-1}$ - treated), and individual stem volume $\left(0.63 \mathrm{dm}^{3} \mathrm{dm}^{3-1}\right.$ year-1 - control, $1.46 \mathrm{dm}^{3}$ $\mathrm{dm}^{3-1}$ year $^{-1}-$ treated) increased for the treated plots.

Although large trees remain large in absolute terms, smaller trees may exhibit greater relative growth rates (Bella and DeFranceschi 1974). The absolute and relative growth rates of individuals from the four crown classes for the five year period following the thinning treatments were summarized (Table 4). As anticipated, absolute height, diameter, and stem volume growth rates decreased incrementally from dominant to suppressed crown classes. However, all relative growth rates increased from dominant to intermediate but then declined for those individuals classified as suppressed. This relationship can be utilized when designing both pre-commercial and, possibly, commercial thinning strategies. For example, if removals focused on suppressed trees in pre-commercial thinning operations, this would eliminate those individuals anticipated to provide ineffective growth responses and increase the growing space for the remaining stems. The largest mean height $(517 \mathrm{~cm}), \mathrm{DBH}(6.0 \mathrm{~cm})$, and individual stem volumes $\left(10.8 \mathrm{dm}^{3}\right)$ occurred on the operational plot associated with this study (Table 1). However, the actual density achieved in this thinning (2929 stems ha- ${ }^{-1}$ ) was greater than the target of $2500 \mathrm{stems} \mathrm{ha}^{-1}$. At this density, insufficient growing space was released to maximize growth response, resulting in low to moderate relative growth rates over the five year measurement period.

If the relationship of trees within the mid-crown classes achieving the highest relative growth rates is maintained over time, subsequent thinning operations could remove the dominant and suppressed trees and leave individuals within the codominant and intermediate crown classes without affecting the 
Table 3. Summary of variance components and significance of pre-commercial thinning treatments generated by Analysis of Covariance for growth parameters 5 years after thinning

\begin{tabular}{|c|c|c|c|c|c|c|c|c|c|c|}
\hline \multirow{2}{*}{$\begin{array}{l}\text { Source of } \\
\text { variation }\end{array}$} & \multirow[b]{2}{*}{ Df } & \multicolumn{3}{|c|}{ Height } & \multicolumn{3}{|c|}{ DBH } & \multicolumn{3}{|c|}{ Stem volume } \\
\hline & & SS & $F$-Ratio & $\operatorname{Pr}>F$ & SS & $F$-Ratio & Pr $>$ F & SS & $F$-Ratio & $\operatorname{Pr}>F$ \\
\hline Covariate & 1 & 3920243 & 1335 & 0.000 & 1707 & 2893 & 0.000 & 23743 & 3500 & 0.000 \\
\hline Block & 3 & 26891 & 3.1 & 0.028 & 0.34 & 0.2 & 0.900 & 8.7 & 0.4 & 0.730 \\
\hline Spacing & (5) & (81305) & (5.5) & $(0.000)$ & (216) & (73) & $(0.000)$ & (1108) & (33) & $(0.000)$ \\
\hline Linear & 1 & 28067 & 9.6 & 0.000 & 211 & 358 & 0.000 & 1065 & 157 & 0.000 \\
\hline Quadratic & 1 & 3209 & 1.1 & 0.302 & 1.2 & 2.0 & 0.160 & 4 & 0.6 & 0.460 \\
\hline Lack of fit & 3 & 50029 & 5.7 & 0.000 & 3.8 & 2.2 & 0.087 & 39 & 1.9 & 0.116 \\
\hline Error & $\underline{708}$ & $\underline{2079827}$ & & & 409 & & & 4804 & & \\
\hline Total & 717 & 6933288 & & & 2423 & & & 32337 & & \\
\hline
\end{tabular}

${ }^{1}$ Parentheses are used to denote that the degrees of freedom and sums of squares associated with spacing were partitioned into the linear, quadratic, and lack of fit components of variance.

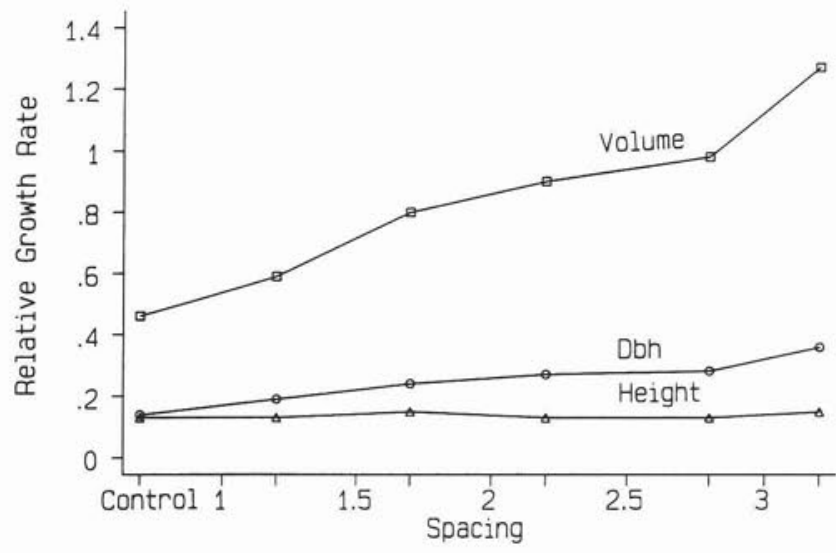

Figure 2. Depiction of linear relationship between the growth response variables and density five years after thinning of a 9-yearold jack pine stand.

growth potential of the remaining stand. This approach could provide a reasonable economic return (via the removal of dominant trees), remove the individuals with the lowest growth potential (suppressed trees), and open up the stand for future enhanced growth of the remaining trees (codominant and intermediate trees). However, the high relative growth rates reported in this study need to be verified for older jack pine stands.

Although significant increases in individual tree growth responses to thinning were reported, total stand volumes, 5 years after thinning, were reduced from $126 \mathrm{~m}^{3} \mathrm{ha}^{-1}$ (control) to $9 \mathrm{~m}^{3}$ $\mathrm{ha}^{-1}(3 \mathrm{~m} \times 3 \mathrm{~m})$ as density was decreased (Table 1$)$. This reduction in stand volume has been commonly reported in other thinning studies (Wilson 1952; Cayford 1961; Buckman 1964). However, if the density-volume generalization (Smith 1962) noted previously is correct, then volume $\left(\mathrm{m}^{3} \mathrm{ha}^{-1}\right)$ on all plots should equalize with time with greater individual tree volumes on thinned plots, if thinning was not too severe. Confirmation of this trend is awaiting future measurements.

\section{Form Responses}

A great advantage in increasing individual tree size, over and above improving harvesting efficiency, is the opportunity to produce different products, thereby increasing market flexibility. In the case of jack pine, shifting from a pulpwood market to providing a mixture of sawlog and roundwood material should prove economically beneficial. However, the demands for enhanced wood quality accompanies this shift in product. For example, trees with large and numerous knots, irregularities in stem form, and/or greater amounts of juvenile wood formed as a result of enhanced early growth can produce unstable structural lumber (Zobel and van Buijtenen 1989), as well as lower yields in pulp (Timell 1986). In comparing jack pine plantation versus natural stand growth and development, Janas and Brand (1988) reported a direct relationship between reduced stand densities and lower stem quality.

From Table 5, the influence of thinning intensity on branching characteristics based on crown width and length measurements was found to be highly significant (crown width $F$ ratio $=101.2$, crown length $F$-ratio $=17.2)$. Yang (1987) found a similar response in crown size and an associated larg-

Table 4. Absolute and relative growth rates for jack pine of differing crown classes for a 5 year period after thinning

\begin{tabular}{|c|c|c|c|c|}
\hline \multirow[b]{2}{*}{ Variable } & \multicolumn{4}{|c|}{ Crown class as of 1991} \\
\hline & $\begin{array}{c}\text { Dominant } \\
(n=269)\end{array}$ & $\begin{array}{c}\text { Codominant } \\
(n=239)\end{array}$ & $\begin{array}{c}\text { Intermediate } \\
(n=143)\end{array}$ & $\begin{array}{l}\text { Suppressed } \\
\quad(n=65)\end{array}$ \\
\hline $\begin{array}{l}\text { Height } \\
\text { (absolute, } \mathrm{cm} \text { ) } \\
\text { (relative, } \mathrm{cm} \mathrm{cm}^{-1} \text { year }^{-1} \text { ) }\end{array}$ & $\begin{array}{r}208.09 \\
0.14\end{array}$ & $\begin{array}{r}184.40 \\
0.14\end{array}$ & $\begin{array}{r}162.90 \\
0.15\end{array}$ & $\begin{array}{r}112.90 \\
0.12\end{array}$ \\
\hline $\begin{array}{l}D b h \\
\text { (absolute, } \mathrm{cm} \text { ) } \\
\text { (relative, } \mathrm{cm} \mathrm{cm}^{-1} \text { year }^{-1} \text { ) }\end{array}$ & $\begin{array}{l}3.21 \\
0.21\end{array}$ & $\begin{array}{l}2.76 \\
0.25\end{array}$ & $\begin{array}{l}2.20 \\
0.28\end{array}$ & $\begin{array}{l}1.51 \\
0.26\end{array}$ \\
\hline $\begin{array}{l}\text { Stem volume } \\
\text { (absolute, } \mathrm{dm}^{3} \text { ) } \\
\text { (relative, } \mathrm{dm}^{3} \mathrm{dm}^{3-1} \text { year-1) }\end{array}$ & $\begin{array}{l}9.44 \\
0.80\end{array}$ & $\begin{array}{l}6.07 \\
0.82\end{array}$ & $\begin{array}{l}3.24 \\
0.89\end{array}$ & $\begin{array}{l}1.30 \\
0.70\end{array}$ \\
\hline
\end{tabular}


Table 5. Summary of variance components and significance of pre-commercial thinning treatments generated by Analysis of Covariance for form parameters 5 years after thinning

\begin{tabular}{|c|c|c|c|c|c|c|c|c|c|c|}
\hline \multirow{2}{*}{$\begin{array}{l}\text { Source of } \\
\text { variation }\end{array}$} & \multirow[b]{2}{*}{ Df } & \multicolumn{3}{|c|}{ Crown width } & \multicolumn{3}{|c|}{ Crown length } & \multicolumn{3}{|c|}{ Taper } \\
\hline & & SS & $F$-Ratio & Pr $>F$ & SS & $F$-Ratio & Pr $>F$ & SS & $F$-Ratio & Pr $>F$ \\
\hline Covariate & 1 & 202659 & 1003 & 0.000 & 2744526 & 833 & 0.000 & 177265 & 347 & 0.000 \\
\hline Block & 3 & 4138 & 6.8 & 0.000 & 12244 & 1.20 & 0.295 & 8373 & 5.5 & 0.001 \\
\hline Spacing & $(5)^{1}$ & (110172) & (101) & $(0.000)$ & (282534) & (17) & $(0.000)$ & (201219) & (79) & $(0.000)$ \\
\hline Linear & 1 & 105929 & 634 & 0.000 & 262761 & 80 & 0.000 & 195358 & 382 & 0.000 \\
\hline Quadratic & 1 & 35 & 0.2 & 0.211 & 1497 & 0.5 & 0.520 & 3091 & 6.1 & 0.025 \\
\hline Lack of fit & 3 & 4208 & 7.0 & 0.000 & 18276 & 1.9 & 0.117 & 2770 & 1.8 & 0.127 \\
\hline Error & $\underline{708}$ & 139980 & & & $\underline{2282420}$ & & & $\underline{362050}$ & & \\
\hline Total & 717 & 456949 & & & 5621200 & & & 801643 & & \\
\hline
\end{tabular}

${ }^{1}$ Parentheses are used to denote that the degrees of freedom and sums of squares associated with spacing were partitioned into the linear, quadratic, and lack of fit components of variance.

er production of branchwood in thinned stands. Although stem straightness, in terms of waviness or number and severity of crooks was not evaluated, stem taper was calculated. Taper values (Table 1) prior to the thinning operations ranged from 122 to 134 [based on Forslund (1991) equation (15)]. In 1991, values varied from 155 (control) to $105(3 \mathrm{~m} \times 3 \mathrm{~m})$. In Forslund's taper formula, smaller numbers represent a greater degree of taper. Although changes in stem taper would be expected as individual trees aged due to physiological changes and responses to crown closure, the substantial differences in taper values were a direct response to the severity of thinning (Table 5: $F$-ratio = 78.7). Morris and Forslund (1992), in comparing mature natural jack pine stands, found that variations in stand density could explain up to $41 \%$ of the variation in stem taper. As with the growth parameters, the response models developed for the form variables identified a significant linear trend (crown width: $p=0.000$; crown length: $p=0.000$; taper: $p=0.000$ ). However unlike the growth parameters, form characteristics decreased in a linear fashion as density decreased (Fig. 3). Greater crown width and length values represent a decrease in form due to the increase in branchiness.

A question asked previously: Is there a spacing threshold at which wood quality reduction does not occur (Vassov and Baker 1988)? In the current study, a significant linear trend in crown dimensions and taper occurred as post-thinning density decreased, as depicted in the response model (Table 5; Fig. 3), suggesting that even light thinnings result in crown expansion and taper increases. However, the extent to which these variables relate to actual wood quality changes is unknown. A detailed study of wood properties would be required to determine the extent of this decrease.

\section{Management Implications}

Van Damme and McKee (1990) studied young jack pine stands (2-20 years old) in northwestern Ontario established by a variety of methods, ranging from shelter cones to wildfire. They found mean densities ranging from 5,400 to approximately 25,000 stems ha ${ }^{-1}$ on sites originating from hand-seeding to wildfire, respectively. Jack pine densities for stands established by shelter cone, precision seeding, and aerial seeding ranged from 7,000 to $11,500 \mathrm{stems} \mathrm{ha}^{-1}$. Past recommendations have targeted stands with densities greater than $5,000 \mathrm{stems} \mathrm{ha}^{-1}$ for pre-commercial thinning. However, pre-commercial thinning of jack pine as an operational silvicultural practice must be done
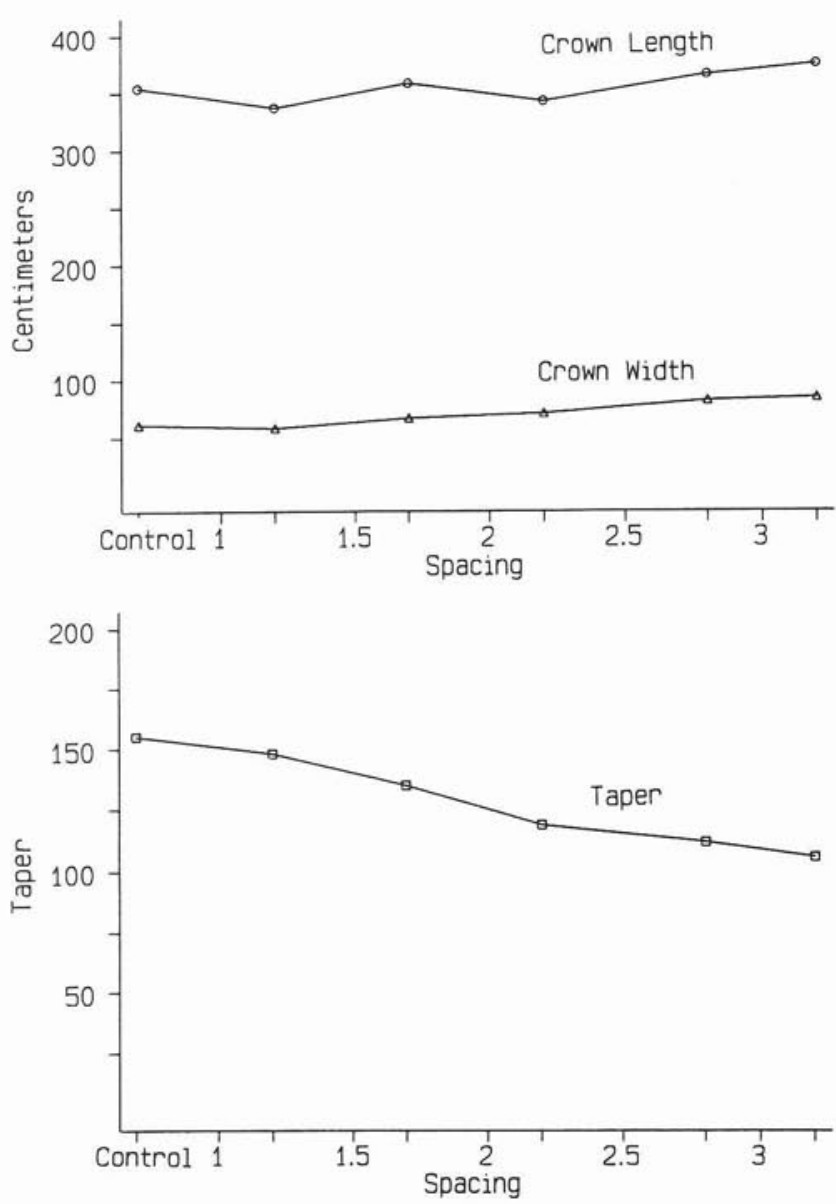

Figure 3. Depiction of linear relationship between the form response variables and density 5 years after thinning of a 9-year-old jack pine stand.

within the context of broader management objectives on any particular forest. A forest supplying a pulp mill will likely have a very different suite of silvicultural prescriptions than a forest supplying a sawlog industry. For example, it may be ecologically and economically justifiable to pre-commercially thin jack pine once, at approximately 10 years of age, for pulpwood. In contrast, if the intended product is sawlogs, it may 


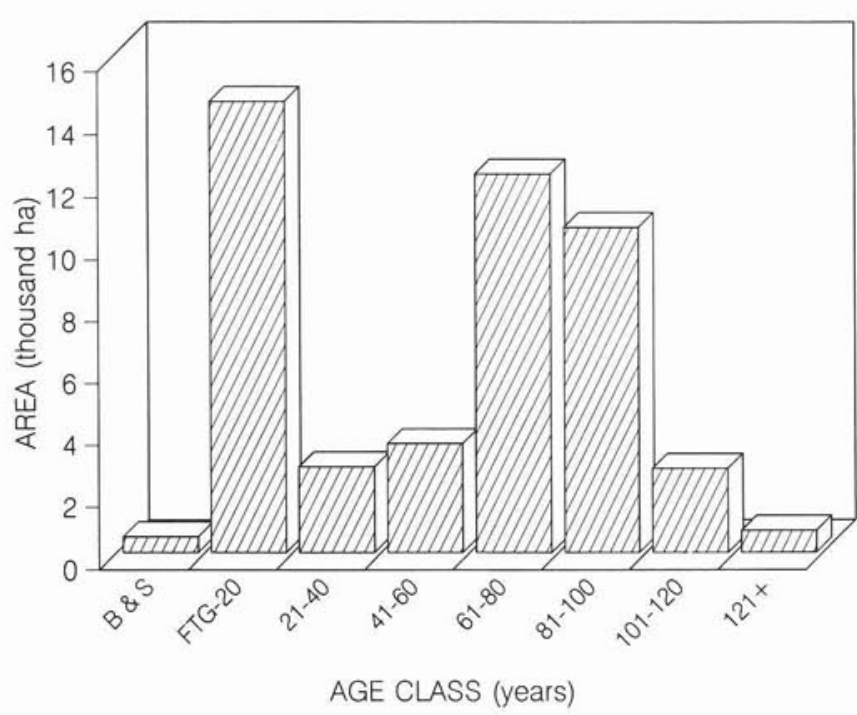

Figure 4. The age-class distribution in the jack pine working group of the Dryden Crown Management Unit (Adopted from: White and Waldram 1991).

be more advantageous to wait until the stand is 25 years old to perform the thinning because in all likelihood, height to live crown would be above the first sawlog, and treatment costs would be amortized over a shorter time period. Although market demand is critical to the decision to thin or not thin, these responses to thinning are only a portion of the factors involved in this decision-making process. Other important factors include: current and anticipated timber supply, distance from manufacturing facilities, availability of capital and manpower, presence of potential damaging agents, and, ultimately, the potential economic gain from thinning.

In the Dryden Crown Forest in which the Dryden Thinning Trial is located, White and Waldram (1991) illustrated an unbalanced age class distribution in the jack pine working group (Fig. 4). Reducing the technical rotation age by pre-commercial thinning young jack pine stands will reduce this wood supply gap. However, the results from this current study demonstrate that this silvicultural treatment has its trade-offs. Although a direct, positive relationship between density and growth response occurred (Fig. 2), form characteristics showed a negative relationship with decreased density (Fig. 3). Morris and Parker (1992) cautioned that it may not be possible to arrive at a final density optimizing jack pine form by selecting a single initial spacing for planting or direct seeding density. Therefore, it seems likely that one or more thinnings may be required to regulate density over the rotation age of a given stand.

\section{Acknowledgements}

The authors would like to recognize and thank Bob White, former Northwestern Region Silviculture Forester, Kenora for his foresight in initiating this field trial and Dr. Keith McClain, former Senior Scientist of the Northern Forest Research Unit, Thunder Bay, for his assistance in establishing the trial in 1986. In addition, the authors greatly appreciated all of the dedicated assistance provided by Glen Niznowski (Northwest Region Science and Technology), Pat Corbett (Area Supervisor - Dryden Crown Forest), and other staff of the OMNR Dryden District in establishing, maintaining, and measuring the trial.

The authors extend their appreciation to the anonymous reviewers for their constructive comments which greatly improved this manuscript.

\section{References}

Bella, I.E. and J.P. deFranceschi. 1974. Analysis of jack pine thinning experiments, Manitoba and Saskatchewan. Can. For. Serv., Publ. No. 1338.

Bella, I.E. and J.P. deFranceschi. 1980. Spacing effects 15 years after planting three conifers in Manitoba. Can. For. Serv. North. For. Res. Cent. Inf. Rep. NOR-X-223.

Benzie, J.W. 1977. Manager's handbook for jack pine in the North Central United States. U.S.D.A. For. Serv., General Tech. Rep. NC32.

Buckman, R.E. 1964. Twenty-two year results of a pre-commercial thinning experiment in jack pine. USDA For. Serv., Lake States For. Exp. Sta., Res. Note LS-46.

Cayford, J.H. 1961. Results of a 1927 jack pine thinning in Saskatchewan. Can. Dep. For., For. Res. Br., Tech. Note No. 107. Davison, R.W. 1984. Jack pine management in the boreal forest of Ontario: North Central Region. pp. 169-172. In C.R. Smith and G. Brown (eds.) Jack Pine Symposium. Canadian Forestry Service, Great Lakes Forest Research Centre, Sault Ste. Marie, Ont. COJFRC Symposium Proceedings O-P-12.

Forslund, R.R. 1991. The power function as a simple stem profile examination tool. Can. J. For. Res. 21: 193-198.

Howse, G.M. 1984. Insect pests of jack pine: biology, damage, and control. pp. 131-138. In C.R. Smith and G. Brown (eds.) Jack Pine Symposium. Canadian Forestry Service, Great Lakes Forest Research Centre, Sault Ste. Marie, Ont. COJFRC Symposium Proceedings OP-12.

Janas, P.S. and D.G. Brand. 1988. Comparative growth and development of planted and natural stands of jack pine. For. Chron. 64: 320328.

Lanner, R.M. 1985. On the insensitivity of height growth to spacing. For. Ecol. Manage. 13: 143-148.

Ledig, F.T. 1974. Concepts of growth analysis. In: C.P.P. Reid and G.H. Fechner (eds.) Proc. Third North Amer. For. Biol. Workshop. Coll. For. Natur. Resour., Colorado State Univ., Fort Collins, CO. Mize, C.W. and R.C. Schultz. 1985. Comparing treatment means correctly and appropriately. Can. J. For. Res. 15: 1142-1148.

Morris, D.M. and W.H. Parker. 1992. Variable-quality form in mature jack pine stands: quantification and relationship with environmental factors. Can. J. For. Res. 22: 279-289.

Morris, D.M. and R.R. Forslund. 1992. The relative importance of competition, microsite, and climate in controlling the stem taper and shape in jack pine. Can. J. For. Res. 22: 1999-2003.

Ontario Ministry of Natural Resources. 1990. Statistics 19881989. Queen's Printer for Ontario, Toronto.

Rudolf, P.O. 1951. Stand density and the development of young jack pine. J. For. 49: 254-255.

Rudolf, P.O. 1965. Jack pine (Pinus banksiana Lamb.) pp. 338-354. In H.A. Fowells (ed.) Silvics of Forest Trees of the United States. U.S.D.A., For. Serv., Agr. Handb. No. 271.

Schoenike, R.E. 1976. Geographical variations in jack pine (Pinus banksiana Lamb.). Univ. Minn. Agr. Exp. Stn. For. Serv., Tech Bull. 304.

Sims, R.A., W.D. Towill, K.A. Baldwin and G.M. Wickware. 1989. Field guide to the forest ecosystem classification for northwestern Ontario. Ont. Min. Nat. Resourc., Queen's Printer for Ontario, Toronto. Smith, C.R. 1984. Pre-commercial thinning in jack pine with particular reference to experiments in northeastern Ontario. pp. 122-130. In C.R. Smith and G. Brown (eds.) Jack Pine Symposium. Canadian Forestry Service, Great Lakes Forest Research Centre, Sault Ste. Marie, Ont. COJFRC Symposium Proceedings O-P-12. 
Smith, D.M. 1962. The practice of silviculture, seventh edition. John Wiley \& Sons, New York.

Timell, T.E. 1986. Compression wood in Gymnosperms. Vol. 2. SpringerVerlag, New York.

United States Department of Agriculture. 1975. Soil taxonomy: A basic soil classification for making and interpreting soil surveys. U.S.D.A., Soil Conservation Ser., Agr. Handb. 436., Washington, D.C. Van Damme, L. and K. McKee. 1990. The extent and nature of seeded jack pine clumping following disturbance in northwestern Ontario. Ont. Min. of Nat. Resour., NWOFTDU Tech. Report \# 58.

Vassov, R. and W.D. Baker. 1988. Pre-commercial thinning of jack pine. Ont. Min. of Nat. Resour., NWOFTDU Tech. Rep. 12. White, R.G. and J.M. Waldram. 1991. Overview of thinning in the Northwestern Region of Ontario. pp. 37-43. In V.F. Haavisto, C.R. Smith and C. Mason (eds.) Space to Grow Symposium. For. Can. and Ont. Min. Nat. Res., Sault Ste. Marie, Ont. Joint Report \# 15.

Wilson, G.M. 1952. Thinning jack pine, Nisbet Forest Reserve, Saskatchewan. Can. Dep. Resour. Dev. For. Res. Div., Res. Note No. 99. Yang, K.C. 1987. Wood properties, wood qualities and silviculture treatments. Quart. J. Chinese For. 20: 7-28.

Zobel, B.J. and J.P. van Buijtenen. 1989. Wood variation: Its causes and controls. Springer-Verlag, New York. 